\title{
Transformations of Iran Sufism in the 12th and 13th Centuries
}

\author{
Seyed Mohammad Hadi Torabi \\ $\mathrm{PhD}$ Research Scholar, University of Mysore, India \\ E-mail: haditorabi.mysore@gmail.com
}

Received: January 10, 2020 Accepted: March 20, 2020 Published: March 28, 2020

doi: 10.5296/jsss.v7i2.16760 URL: https://doi.org/10.5296/jsss.v7i2.16760

\begin{abstract}
The 12th and 13th centuries are among the most important periods in the history of Sufism in Iran. During this period, the emergence of many great elders of Sufism and the establishment of the most famous ways and organized dynasty in Sufism by them, the formation of some of the most important treasures of Islamic Sufism, such as the dressing gown and the permission document of the dynasty, the systematic growth and development of the Monasteries as formal institutions and the social status of Sufis and the influence of Sufism in the development of Persian and Arabic prose and poetic, which in this study, briefly, the transformation and effects of Iranian Sufism are examined.
\end{abstract}

Keywords: Cultural equations, Political equations, Religion, Sufism

\section{Introduction}

Iranian Sufism, which has formed in the context of Islamic Sufism and its influence on the Sufism of the ancient religions in Iran, such as Zoroastrianism and Manichaean, has seen tremendous transformations over time, which undoubtedly caused cultural, political, social and even economic changes that have arisen in Iran has led to many ups and downs in the path of growth and excellence. Prior to the 12th century, Sufism continued to exist as a belief system based on knowledge and paths and a mystical view of religion, in which many groups and branches were formed, but differences of them were mostly in the field of thought and had little effect on the space of the community. Islamic Sufism, both in theory and in its practical form, had plenty of rich content to offer its followers, and even Sufism in its practical field was approaching its peak. Since the beginning of the 12th century, Sufism has become an organized and semi-secret institution and has played a large role in social, cultural and even political equations. 
In this period, due to the attack of Turkish tribes, there was a lot of disruption in Islamic community. In this century, Iran, Transoxiana, Damascus, Asia Minor, Rome and the Caucasus were in the hands of the Seljukites, and Multan, Punjab, and Sindh in the hands of the Ghaznavids. The Kharazmshahian, the Ghorids, and the Qara Khitais were ruling in their respective territories; on the other hand, the Abbasids, who until then were considered great powers, ruled in Iraq and did not have the former power (Sykes, 1993; Iqbal, 1997). Nevertheless, at that time, the Sufis had a desirable position, because many of the governors, ministers and sultans of this covenant supported them by expressing their will to the elders of Sufism. As the Abbasid caliphs like Mustanser and Nasser, as well as Tugril Seljuk, or even ministers of such rulers as Nizam al-Mulk Tusi or in the West of the Islamic world, rulers such as Salahuddin Ayoubi and his/her children have made the construction of Sufi monasteries or Sheikh Shahabdin Suhrawardi, Sahib Avif al-Maref was sent to the embassy by Nasser, the Caliph Abbasi (Trimingam, 1971).

In this period, Sufism co-ordinated with the formal religion and found itself within the framework of the Shari'a, which undoubtedly elders (mashayekh) like Qashiri who defended the right of Sufism to have a legitimate position in community, and the conversion of Ghazali to Sufism and defending it provided the basis for the reconciliation of Sharia and Sufism. After this bondage, on the one hand, works such as Revelations of the unseen, Adab al-Meridīn and Awaref Almaaref were created that emphasized the summery between the tradition and the Shari'a (Nafisi, 1965), and on the other hand, great elders such as Abdul Qadir Gilani, Shahabuddin Abu Hafs Sohrevardi and Najmoddin Kobray came to the conclusion that adherence to the Shari'a were considered as their specific features, such as Najmoddin Kobray and as Abdul Qadir Gilani, Imam in jurisprudence, and about Shahabuddin Abu Hafs Sohrevardi said that the light of the companionship of the prophet is something else (Manawi, 1999). Other specific features of this period are the growth and development of the monasteries. In the preceding centuries, caliphs, princes, ministers, and nobles and peoples had taken steps to build monasteries, but during this time, Abbasi's later caliphs, in addition to building the monasteries and paying their expenses, chose the elders of the Tariqat to Sheikh al-Shoyokhi and headed the government caravanserais (Trimingam,1971). Gradually, the monasteries rituals and ceremonies were expanded, and turned into formal and social organizations where, in addition to performing monasteries affairs, Islamic science education, discussions on spiritual matters, preaching and guidance, and the compilation of mystical books were also dealt with (Kiani, 2001). These monasteries were even specially designed for women of Sufi, which were headed by women, among them the most famous ones are caravanserai of Fatemeh Razieh in Baghdad and caravanserai of Baghdadiyeh in Cairo under the direction of Zaynab Bint Abul Barakat (Trimingam, 1971).

In this period, the emergence of the great elders of Sufism is also important. The elders such as Abu al-Najibab Suhrawardi, Shahabuddin Abu Hafs Sohrawardi, founder of the Suhrawardiyahah way (Tariqeh); Niemoddin Kobary, the founder of the Kobrayeh way, renowned for Sheikh Valerashh, who has taught such distinguished students as Majdaddin Baghdadi, Sa'd al-Din Hammuyah, Seyfuddin Bakhrzayi and Raziddin Ali Lala, and each were the great elders of that time. Abdul Qadir Gilani, the founder of the Qadiriyah way; Khwaja Aboyaqoub Yusef Hamedani, the founder of the Khojgan way and Roozbehan 
BaGholi Shirazi, the founder of Rouzbehani way, were among those who, along with reconciliation of Tariqat and sharia, the support of the rulers of Sufism, the growth and development of the monasteries, were extended the Sufism and the emergence of the first Sufi methods in this period.

Before formatting these ways, elders, such as Hojawari, have named several Sufi ways, which reflects on the conclusion that the emergence of the mentioned ways returned to their differences of opinion, and not the difference in the manner of worship and execution rites.

In addition, they did not have a coherent structural ways and had a clear religious system and a hierarchy of their own.

The ways of the Sufis were not only in the rites of conduct and in the way of conduct, but also in the importance of the Sharia, and did not emphasize the observance of Sharia's laws and norms. These ways later became a network of Sufism organizations spread throughout the Muslim world. The system of these ways, during its evolution, influenced both Islamic sciences and the general circle of belief and ritual in Islamic communities, as religious rituals roughly performed with the same precision that was carried out in the mosques in the monasteries. And Sufi elders, just like the traditional scholars in religious schools, only when official permission from their teachers and guidance raincoats were qualified to guide the followers (Bakharzi, 2004).

The most important ways that were formed during these two centuries were Suhrawardiyaheh, Kobaryeh, Qadiriyah, Rafieh, Khajagan, Cheshtiyeh and Mowlavi. In addition, other smaller ways such as Roozbehānieh in Fars and Yosewi in Central Asia and the Caucasus, and Bektashiyah in Anatolia also appeared (Trimingam, 1971).

The influence of Sufism in Persian literature is another feature of this period. During this period, the elders of Sufism, with particular attention to the training of lawyers and guidance of the people, drew Persian poetry and prose from the courier circles and used it to express the high ethical-mysticism and educational values (Safa, 1993). In addition, since the construction of Sufism works on taste, they brought poetry and prose with it and gave them new ideas of thought. Though most of the mystical prose works of this period have been written using simple Persian language, but the prose of Sufism in them sometimes, like mystical poems, has romantic and passionate themes that are Abhraz-e-Alashekin by Roozbehan Baqli Shirazi and Tamhidat by Ain-al-Khedat Hamedani were from this work type. In relation to the poetry that contains the epistemic teachings of Sufism, though, for the past two centuries, there have been examples of teaching poetry in the portions and imethic of Abu Said Abu al-Khair and the works of Khwaja Abdullah Ansari, but the highest and strongest manifestations of teaching poetry in Haditha Sanai and then it was formed in Attar and Rumi's Masnavi (Bertles, 1977).

One of the most significant events that influenced Sufism during these two centuries was the devastating Mongol attack. The Mughal tribesmen from the eastern and southern Asian yellow skin tribes seized almost all Muslim worlds with a number of attacks, killing Al-MustesMolla in Baghdad, abolished the 525 year Abbasid caliphate and moved to the Egyptian border. During these attacks, many people were killed, some cities were completely destroyed, and in some other cities schools, numerous mosques and libraries were destroyed. 
Meanwhile, some Sufis also did not remain secure from the Mongol fortress, as Farid al-Din Attar was murdered in the Mongol attack of Neyshabur (Forouzanfar, 2003), and Najmuddin Kobray, one of the great elders of Sufism and the founder of the Kubrayeh dynasty in the killing of Khwarizm, he left his dress, weared in a war dress, and killed by the Mongols.

During the Mongol attacks, many people who were able to escape this tragedy escaped to safe areas. These areas, which were largely confined to the Mongols, due to the allegiance of their rulers and their sultans to the Mongols, and to their acceptance, were Rome and Asia Minor, Western India and some areas under the rule of the local authorities, most notably the Fars and southern Iran (Iqbal, 1997). These areas were a safe haven for Sufis to escape the Mughal attack. Therefore, Baha'u'l-Din Valad, the famous Sufi of Khorasan, along with his family and relatives, including his teenage son, Jalaluddin Balkhi, due to the Nughal attack came to Baghdad, Mecca and Sham moved and then, at the invitation of Aladdin Kikhbad, the Roman Seljuk king, went to Konya and was supported by him. At that time, Najmiddin Razi went from Khwarazm to Ray and Hamedan, and from there went to Kayseri to write his famous work The Path of God's Bondsmen from Origin to Return (Riahi, 1991). Seifuddin Bakhrazai and Saad Al-Din Hammieh, both of Sheikh Najmuddin Kobray's disciples, were expelled from the city by the orders of the Sheikh before the capture of Khwarizm by the Mongol army. Bakhrzayi went to Bukhara and settled there, and Hammieh traveled to Mazandaran, Iraq, Sham and Hijaz, and remained in those territories for about a quarter of a century.

Despite all the damage that the Mongol attack left behind, the relative calm created after the initial attacks in the occupied territories created favorable conditions for cultural communication with the exchange of ideas among the Mongol invasive lands. Other, it prompted the spread of Islam in the non-Muslim lands, especially in the East Asian regions. In the meantime, some of the Sufism elders who migrated from their areas due to Mongol attacks have expanded the teachings of Sufism in safer areas. In addition, internal disagreements that occurred among the rulers and sometimes the members of the Revolutionary Guards, due to the occupation of some areas, causing political and social disturbances, somehow spread the thoughts of asceticism and the quitting of the world among some people, such as the Ash'arite school, Considering all the oppression of the Mongols as divine providence and punishing them, they turned to determinism that Sufism and Sufi thoughts were in fact a healing remedy before them, and it was natural that such an attitude be strengthened by the Mughal rulers. Of course, one should not ignore the fact that the influence of the rich spiritual culture as well as the beliefs of the Mongol rulers on the effective forces of the occultation of the Sufism elders also provided a relative tendency to Sufism.

Many Mughal rulers, such as Ghazan Khan, Sultan Mohammad Khodabandeh (Olijatou) and Sultan Abu Sa'id, as well as some ministers like Khaje Nasir al-Din Tusi, Rashid al-Din Fazlullah Hamedani and his son Khwaja Ghiyat al-Din Mohammad, tended to Sufism and forcing them to sell their wealth to the Sufis and the construction of Sufi monasteries and the expansion of schools and Sufi education classes by them appeared. As the monasteries built by Ghazan Khan in Tabriz and Hamedan, the monastery was built by Olijatou in Soltaniyeh and Khoja Rashid al-Din monastery in Yazd (Rashid al-Din et al., 1940) and the Mongols 
gave the school management to Saifuddin Bakhrzai that the mother of Khan Mongol had made with a thousand pillows of silver from their property in Bukhara. Sadr al-Din Ibrahim Hamoumieh, who initiated the Qazan Khan's ceremony-sixth Khan of Mongol after Hulagu Khan- to Islam (Rashid al-Din et al., 1940), and Alaa al-Dīnula by effort of mediated between him and Sultan Abu Sa'id at the request of one of the great Mongol empires.

Another result of the Mughal attack was the grip of the Shia religion and its approach to Sufism. From the beginning of this incident, and especially after the collapse of the Abbasid caliphate and the Mongol empire in Iraq, on the one hand, the Shiites found more freedom and were able to pay more attention to their religious affairs, and on the other hand, gradually, Shiite tendencies among Sufi, and tendencies in moderate Shiite appeared in the Sunni congregations. In addition, some Ismailites who failed by the Mongols and engaged in secret activities joined the Sufi dynasties or created new branches in those dynasties (Nasr, 1975).

By emergence of Ibn Arabi, along with the arrival of theoretical Sufism to its peak, was another major event of these two centuries. Mohiyeddin ibn Arabi is one of the most prominent and influential Sufis of the Islamic world. His numerous works, including hundreds of titles, include topics such as cosmology, theology, Marafat al-Nafs, Tafsire Qur'an, jurisprudence, hadith, journey, and any other subject that somehow deals with religious and spiritual issues (Nasr, 1975). Not only did it had a tremendous impact on the Muslim world, but also some scholars believed that some of the works of Western writers also influenced some of the scholars, the Paradiso by Dante, a florasic poet who born twenty-five years after death Ibn Arabi was considered as influenced by his works (Palacios, 2012).

By emergence of Ibn Arabi, Sufi beliefs and thoughts that were in the form of theoretical sophist, and so far more sporadic and inconsistent in the works of the Sufi elders, were arranged, and Sufism became the color of science and philosophical debates, and mystic science was recognized as one of the branches of Islamic sciences (Qaisiri et al., 1978). This theoretical expression of mystical cosmology was continued by his philosophical students who sometimes had independent thinking in his reading of his works and left an important influence on the process of understanding others from his teachings and the formation of Ibn Arabi's school.

Ibn 'Arabi's influence on the whole Islamic world is evident from the plurality of inscriptions he has written on his works in different regions such as India, Minor Asia, Syria, Egypt, and even China and the Malayan lands, but it can be argued that his statement has been considered in Iran more than everywhere, and has been influential, so much so that the Iranian people had the most inscriptions effect on his works (Carbon, 1998). In expanding the teachings of Ibn Arabi in Iran, Sadr al-Din Qunavi, the stepson and the great scholar of the teachings of Ibn Arabi had most contribution because he was the first to communicate between his teachings and Sufism in Iran, and he was able to transmits Ibn Arabi's thoughts from the Mystical-Sami language and culture to the mystical language and culture in the Iranian environment (Chitak, 1991). After him, Sufis such as Mouyeddin Jandi, Tajeddin ibn Husayn Khwarazmi, Fakhreddin Araghi, Abdul Razzak Kashani, Dawud bin Mahmud Qaisari, Mahmoud Shabestari and Abdul Rahman Jami had a great influence on the development of Ibn Arabi's statements among the Iranians. 
Different Sufi dynasties have also influenced Ibn Arabi's teachings. The elders of Suhrawardiyah dynasty were closely associated with Ibn Arabi and his school from the very beginning. There was a lot of evidence in this regard, including the visit of the Shahabuddin Suhrawardi, the founder of this dynasty, with Ibn Arabi (Yafei, 1970); Providing for the training of Sadr al-Din Qunavi to Oohad al-Din Kermani from the elders of Suhrawardi by the Ibn Arabi; the Qunavi's will to be buried with Ibn Arabi's derss and Sajjadah of Oohad al-Din Kermani (Karbalai et al., 1965); following some of the great inscriptors of Ibn Arabi's school like Saeed Eddin Farghani, Abdul Razzaq Kashi and Davood Qaisari from Suhrawardiyah (Jami et al., 2003).

In Kabrayeh dynasty, the influence of Ibn Arabi's teachings was different. Though his teachings had penetrated the dynasty from the very beginning, Azizeddin Nasafi and Abolmfakh Yahya Bakhrzai, from the Kabrayeh elders, tried to establish a link between the teachings of this way and Ibn Arabi, but the anti-philosophical orientation of this dynasty and the opposition of some of his elders such as Nour Al-Din Abdul Rahman Esfarayni And his disciple, Alledouleh By effort of, caused the stagnation of this bond. After Alledouleh by effort of, the teachings of the Kabrayeh dynasty were joined by Ali Hamedani, with the statements of Ibn Arabi, and after dividing the dynasty into two branches of Zahabieh and Nourbakhshieh, the elders of both branches showed clear tendencies in the teachings of Ibn Arabi (Riyadh et al., 1991).

In Naghshbandieh dynasty, even though one of the opponents of Ibn Arabi called Sheikh Ahmad Sarhandi, under the influence of Alledouleh by effort of, expressed the theory of unity of intuition against the unity of existence of Ibn Al-Arabi, but before and after him, the elders of this dynasty tended to teachings of Ibn Arabi, obviously. Prior to Sardani, the Caliphs of Baha'uddin Naghshband, Khwaja Mohammad Parsa, Khwaja Obaidullah Ahrar, and finally Abdul Rahman Jami, were the inscriptor of Ibn Arabi's thoughts. Khajeh Mohammad Parsa reads the bezels of wisdom (Fusus al-Hekm) and Al-Fotouyat al Makayah of Ibn al-Arabi as life and heart (Kashefi et al.,1977) and both he and Abdul Rahman Jami, wrote on the inscriptions of Ibn Arabi and, in particular, the bezels of wisdom. After Serhandi, the opposition to Ibn Al-Arabi did not end in Naghshbandieh, and a century after him, one of the elders of Naqshbandiyah, Shah Wali Allah Dehlavi, attempted to create an agreement between Ibn Arabi and Sarhandi in the Faisaleh Vahde al-Vojud and al-Shohod treatise, and show that their differences are not fundamentally different (Fisher et al., 1968).

Cheshtieh dynasty was also influenced by Ibn Arabi's statements. Although elders of Cheshtieh initially considered works such as Avaref al-Maref Sohrevardi and Kashif-al-Mahjoub Hojawari as their main educational books, and some of elders like Seyyed Mohammad Gisoderaz opposed Ibn Arabi's statement, but the elders of this way later turned to Ibn Arabi's teachings and promoted his school, including Abdul Qados Gonghuhi, who wrote a description of Ibn Arabi's writings, Nizamdin Tanshiri who explained the Fakhr al-Din al-Iraqi, and Mohabullah Al-Abbadi, who wrote numerous works to promote the statements of Ibn Arabi statements (Nezami et al., 1975). The Nematollahieh dynasty from the very beginning also had a clear tendency toward the teachings of Ibn Arabi and the numerous Persian treatises of Shah Nematollah Vali, written according to Ibn Arabi's school, also testify to this claim (Jahangiri et al., 1996). 
The teachings of Ibn Arabi were also considered in the Shazlieh dynasty, and some of the great elders of this dynasty, such as Ibn Ata'alllah Eskandari and Mohammad Maqrabi Shazlī, put Ibn Arabi in great measure (Tafazani, 2003). The similarity between some of the teachings of Ibn Arabi and the teachings of the Shiites suggests that he is influenced by Shia sources, and even some of the topics in his works are as if written by a Shia mystic (Sheibi et al., 1969). However, it should be said that his influence on Shia mysticism was less than his effectiveness. The teachings of Ibn Arabi were well received by the Shiite mystics, and along with his Sunni inscriptors, Shiite inscriptors such as Seyyed Haydar Amoli, Ibn Tarek Esfahani and Ibn Abi Jomhour Ehsaei, with some changes, introduced his teachings into Shia mysticism. Meanwhile, Seyyed Haydar Amoli's role is more prominent than others, and his works are a turning point in the integration of Ibn Arabi's teachings with Shiite mysticism (Arabi, 1979). Thus, the Ibn Arabi school which first emerged from the Sunni era, was warmly accepted in Shiite circles and was absorbed in Shia Sufi ways such as Nematollahieh, Nourbakhshieh, and Zahabibeh (Nasr, 1975).

In addition to the above, (Arabi, 1979) was influential in Sufi literature after himself, both in content and in the style of writing. Prior to him, most of the Sufi writers emphasized practical and ethical issues, but after him, the works of Sufism focused more on theoretical subjects such as monotheism, prophecy and resurrection. Also, with the advent of Ibn Arabi's school, there appeared Sufi works full of specific terms of the school, including complex and incomprehensible subjects for all, as some inscriptors wrote the works of Ibn Arabi in the form of terminology dictionary. Also, some followers of Ibn Arabi tried to express his teachings in the form of poetry, among which, Gulshan Raz by Sheikh Mahmud Shabestari is one of the best examples of this effort. In addition, the poetic style of Fakhr al-Din al-Iraqi in the narrative of Ibn Arabi's school in Lamakh, as well as some of his sonnets, became an example of some Sufi poets. Shah Nematollah Vali, leader of Nematollahieh dynasty, also described the teachings of Ibn Arabi in his poems, followed by Mohammad Shirin Maghrebi and Abdul Rahman Jami (Zarinkoub, 1999). Despite the effects that the teachings of Ibn Arabi left on the teachings of Sufism, these teachings were more influenced by Sufi's theoretical works and did not have much effect on Sufi practical works after him.

In other words, in spite of the fact that some of the practical works of Sufi such as Manazele al-Sael by Afif al-Din Talmansani and The Abdul Razaq are written based on Ibn Arabi's school, and in some of the practical books of Sufi, such as Urad al-Ahbab, Abolmfakr Yahya Bakhrazi (Bakhrazi and et al., 2004), there have also been references to the use of the works of Ibn Arabi, but Ibn Arabi's influence on Sufi practical works is not so tangible.

\section{Conclusions}

The $12^{\text {th }}$ and $13^{\text {th }}$ centuries are one of the most important periods in the history of Sufism in Iran. In this period, the emergence of many great elders of Sufism were occurred, some of whom are founder the most famous ways and organizational dynasties of their time in Sufism. In this period, the formation of some of the most important treasures of Islamic Sufism, such as the dressing gown and the permission document of the dynasty, the systematic growth and development of the Monasteries as formal institutions and the social status of Sufis and the influence of Sufism in the development of Persian and Arabic prose and poetic, but two major transformations of the brutal attack of the Mongols into Islamic lands, as well as the 
emergence of the great mystic of the seventh century, Muhei al-Din Ibn Arabi, were the most important events of this era. Mongol dominance over Islamic lands, despite all the damage that has inflicted on the body of Muslim culture and community, has created an open space for propaganda after the period of stumbling down the Abbasid and the rise of the elders of Sufism among the governments and people, and this is the reason for the creation of various and great Sufi dynasties, and the link between Sufism and Shia.

\section{References}

Bakhrezi, Y., \& Urad al-Ahbab. (2004). Attempted by Iraj Afshar, Tehran.

Bertels, Y. E. (1977). Sufism and Sufism literature, Translated by Sirous Izadi, Tehran.

Corbin, H. (1998). Alone with the Alone: Creative Imagination in the Șuffism of Ibn 'arabī (Vol. 149). Princeton University Press.

Chitak, W. (1991). Introduction to the critique of Al Nusus Abdul Rahman Jami, Tehran.

Carbon, H. (1989). Introduction to Jamea al-Asrar and the Manba of Al-Anwar Haydar Amoli, Tehran.

Fisher, W. B., Boyle, J. A., Boyle, J. A., \& Frye, R. N. (Eds.). (1968). The Cambridge History of Iran (Vol. 5). Cambridge University Press.

Forouzanfar, B. (1995). Citation and critique and analysis of the works of Sheikh Farid al-Din Mohammad Attar Neyshabouri, Tehran.

Ghanimi Tafazani, Abu al-Wafa, Al-Tirakah Al-Akbarieh, Al-Ketab al-Tazakari (also); Forouzanfar, B. (2003). Thesis in the Study of Life of Maulana Jalal al-Din Mohammad, Tehran.

Ibn, A., Elkaml; Ibn Emad, Abdulahi, Shaztar al-Zahab. (1979). Beirut.

Iqbal Ashtiani, A., Mongolian. (1997). History, early Timurid, Tehran.

Jami, A. R. (2003). Nefat al-Elans, by Mahmoud Abedi, Tehran.

Jahangiri, M., Mohiyeddin ibn Arabi (1996). The prominent figure of Islamic mysticism, Tehran.

Kashefi, A., Rashat Ayn al-Hayat. (1977). By effort of Ali Asghar Moinian, Tehran.

Karbalai, H. H. (1965). Rawzat al-Jananan, by the efforts of Jafar Soltan al-Qarai, Tehran.

Kiani, M. (2001). History of monastery in Iran, Tehran.

Manawi, Mohammad Abdul Rauf al-Kawkab al-Dariyat. (1999). By effort of Mohammad Adib Jadar, Beirut.

Nasafi, Aziz al-Din, Kashfol Al-HAqayegh. (1965). By effort of Ahmad Mahdavi Damghani, Tehran.

Nasr, H. (1975). Three Muslim Witches, Translated by Ahmad Aram, Tehran. 


\section{Al Macrothink}

Journal of Social Science Studies

ISSN 2329-9150

2020, Vol. 7, No. 2

Nasr, S. H., «Ibn a Arabi in the Persian Speaking World», (vide: PB, Alketab ot- tazkāri); Sufi Essays, London, 1972; Rizvi, A. A., A History of Sufism in India, New Delhi, 1986.

Nezami, K. A. (1975). History of Cheshat elders, Karachi.

Nafisi, S. (1998). The source of Sufism in Iran, Tehran.

Palacios, M. A. (2012). Islam and the Divine Comedy. Routledge.

Qaisiri, D., \& Rasel Qaisari. (1978). By effort of Jalaleddin Ashtiani, Tehran.

Rashid al-Din Fazlollah. (1940). Mubarak Ghazani's History, attemped by Karl Ian, Hartfred.

Riahi, M. A. (1991). Introduction to Mirsad al-'Abad (see: also, Najmeddin Razi); Riyadh, M., the works and poems of Mirsaid Ali Hamedani, Islamabad.

Sykes, P. (1993). History of Iran, Translated by Mohammad Taghi Fakhrdai Gilani, Tehran.

Sheibi, Kamel Mostafa, Al-Selah Bein al-Tasavof al-Tashaia. (1969) Cairo.

Safa, Z. (1993). History of Literature in Iran, Tehran.

Trimingham, S. O. J. (1971). Spencer Trimingham, The Sufi Orders in Islam.

Yafaei, A. (1970). Morat al-Janan, Beirut.

Zarinkoub, A.H. (1999). Values of Sufi Heritage, Tehran.

\section{Copyright Disclaimer}

Copyright for this article is retained by the author(s), with first publication rights granted to the journal.

This is an open-access article distributed under the terms and conditions of the Creative Commons Attribution license (http://creativecommons.org/licenses/by/3.0/). 